\title{
Panel Session: Targeted Harassment in Engineering Education: What It Looks Like, Why Now, and What Is at Stake
}

\author{
Dr. Alice L Pawley, Purdue University-Main Campus, West Lafayette (College of Engineering)
}

Alice L. Pawley is an Associate Professor in the School of Engineering Education and an affiliate faculty member in the Gender, Women's and Sexuality Studies Program and the Division of Environmental and Ecological Engineering at Purdue University. Prof. Pawley's goal through her work at Purdue is to help people, including the engineering education profession, develop a vision of engineering education as more inclusive, engaged, and socially just. She runs the Feminist Research in Engineering Education Group whose diverse projects and group members are described at pawleyresearch.org. She received a CAREER award in 2010 and a PECASE award in 2012 for her project researching the stories of undergraduate engineering women and men of color and white women. She has received ASEE-ERM's best paper award for her CAREER research, and the Denice Denton Emerging Leader award from the Anita Borg Institute, both in 2013. She was co-PI of Purdue's ADVANCE program from 2008-2014, focusing on the underrepresentation of women in STEM faculty positions. She helped found, fund, and grow the PEER Collaborative, a peer mentoring group of early career and recently tenured faculty and research staff primarily evaluated based on their engineering education research productivity. She can be contacted by email at apawley@purdue.edu.

\section{Dr. Erin A. Cech, University of Michigan}

Erin Cech joined the department of sociology at the University of Michigan as an assistant professor in 2016. Prior to that she was a Postdoctoral Fellow at the Clayman Institute for Gender Research at Stanford University and was on faculty at Rice University. She earned her Ph.D. in Sociology from the University of California, San Diego. Cech's research seeks to uncover seemingly benign cultural mechanisms of inequality reproduction - particularly around cultural logics in popular explanations of inequality; gender, sexual identity and racial/ethnic inequality in science and engineering; and cultural definitions of "good work" and "good workers."

\section{Dr. Donna M Riley, Purdue University-Main Campus, West Lafayette (College of Engineering)}

Donna Riley is Kamyar Haghighi Head of the School of Engineering Education and Professor of Engineering Education at Purdue University.

\section{Dr. Stephanie Farrell, Rowan University}

Dr. Stephanie Farrell is Professor and Founding Chair of Experiential Engineering Education at Rowan University (USA). Prior to 2016 she was a faculty member in Chemical Engineering at Rowan for eighteen years. Dr. Farrell has contributed to engineering education through her work in inductive pedagogy, spatial skills, and inclusion and diversity. She has been honored by the American Society of Engineering Education with several teaching awards such as the 2004 National Outstanding Teaching Medal and the 2005 Quinn Award for experiential learning, and she was 2014-15 Fulbright Scholar in Engineering Education at Dublin Institute of Technology (Ireland)tephanie Farrell is Professor and Founding Chair of Experiential Engineering Education at Rowan University (USA) and was 2014-15 Fulbright Scholar in Engineering Education at Dublin Institute of Technology (Ireland). 


\title{
Panel session: \\ Targeted harassment in engineering education: what it looks like, why now, and what is at stake
}

\begin{abstract}
The marginalization of critical perspectives that has plagued continental philosophers, heterodox economists, women's and ethnic studies scholars for decades is now affecting STEM diversity scholars, and engineering education equity scholars in particular. There is a reported rise nationwide in the targeted harassment of academics for their scholarship. We now have multiple cases in engineering education to consider. What are the stakes of this phenomenon and our institutions' responses? Several engineering education scholars who have been targeted will serve on a panel in this session to talk about the disciplinarity of this increase, its form and tone, ways institutions can better support the work of these scholars, and how scholars can bolster one another.
\end{abstract}

\section{Introduction}

Dear Ms. Cech, I filled out your survey earlier today and was totally disgusted about the lack of focus on technical issues related to STEM...I was severely irked by these questions - only a "social scientist" could have thought they were indicative of significant aspects of REAL scientists' lives and careers. I strongly suspect that you know nothing about science and scientists.

I already replied to your 'survey' which did not seem as focused on an overall survey regarding STEM demographics - as it purports - as it is about establishing certain aspects of identity politics.... w will follow your progress and bring this up during any methodological review regarding the 'scientific validity' of your survey results. Good day.

Feedback received via email from a survey respondent as part of an NSF-funded research study.

Scholars of engineering education equality and diversity - particularly those from historically underrepresented categories in STEM - have noticed an uptick in a different kind of public response to their work. Marginalization of critical perspectives has plagued scholars across the academy for decades - from continental philosophers to heterodox economists to women's and ethnic studies scholars. We see a notable rise in similar responses now affecting STEM diversity scholars, and engineering education equity scholars in particular. Rather than methodological or theoretical disagreements about the substance of the research typical of academic debates, these responses are often aggressive, personal, and derogatory - in short, ad hominem attacks and harassment.

Such harassment differs from disagreement (academic or not) in its tone and approach: harassment is disconnected from reason and fact, often threatens violence, and may use gendered, racial, or homophobic epithets. It often demeans or dismisses the scholarly competence of the researcher. Targeted harassment may come at high volume from a variety of 
sources, but can include attacks on social media or through sending hate email or physical mail. It may include threats to track a researcher in person or online, and is designed to scare the researcher from persisting along a certain line of inquiry.

As an example, consider the following email, received by Donna Riley just days before the Purdue Trustees voted on her appointment as Head of the School of Engineering Education:

Wow...a once great University, now infiltrated w/ KGB communist scumbags like yourself. (and of course you voted for that nigger commie monkey that stunk up the white house [sic] for 8 yrs)

Dean My ASS......your [sic] lucky I'm not a student (or parent) of Purdue, you bitch.

You listen to Michael Savage, and start about $22 \mathrm{~min}, 15$ seconds into the podcast. There are millions of people that listen to him, and now (thanks to Savage), we all know who you are, \& what you are. You've been exposed.

Remember, there's an underground counter-revolution (to the commie revolution) in place....we got TRUMP elected, and the new America is going after all the Commie scumbags. A great purging is coming.

Can't wait to here [sic] about the new job you'll have cleaning the toilets at Purdue....the job you're are actually qualified for. !!! LOL

Now, kiss my white Irish Ass, BITCH

\section{J. Wilson, Personal Communication, August 5, 2017.}

Other email, among dozens received, targeted not only Riley but also her staff, her dean, Purdue's president, and her department head colleagues. In addition to hostile email, Riley's personal social media was targeted including YouTube, Twitter, and even her exercise app. The social media of her department and other departments and the Dean of Engineering's office at Purdue were also targeted. Riley's accounts have been made private, ultimately limiting the impact and reach of her research activity as well as connectedness to others in her personal social networks.

The American Association of University Professors (AAUP) has identified the targeted harassment of faculty, including contingent faculty, as a threat to the core of academic freedom. The professional standard of academic freedom was developed by AAUP in 1940 [1]. It asserts, among other things, that teachers are entitled to full freedom in their research and publication of results, as well as full freedom in the classroom in discussing their subject. AAUP has assessed that the overwhelming preponderance of targeted harassment threats come from politically rightwing sources [2]. Journalists investigating the targeted harassment of faculty have identified key portals like Campus Reform as sources for internet trolls to identify academics to harass [3]. When articles targeting faculty gather steam through sharing and republication in multiple media 
outlets, harassment can intensify in both frequency and severity of threat to the individual and the campus.

This targeted harassment is of concern to the ASEE scholarly community not only because it threatens members of our community but also because it may have a "chilling" effect on research and innovation in engineering education: scholars, especially those who are part of historically marginalized groups, or those in more vulnerable positions in the academy, may avoid research in engineering equality out of fear of the personal and professional effects of this harassment.

This paper motivates and provides context for an invited LEES panel on targeted harassment in engineering education. Several engineering education scholars who have been targeted will present as panelists in this session to talk about the disciplinarity of this increase, its form and tone, ways institutions can better support the work of these scholars, and how scholars can support one another. This paper itself begins to document for the archival record the targeted harassment of engineering education scholars as part of institutional response to resist.

\section{Targeted Harassment in Engineering Education: Personal Accounts}

Cech has received over 50 emails from science and engineering professionals in response to the fielding of a survey of STEM-related professional organization members. These typically take the form of questioning or dismissing entirely her scholarly expertise and raising objection to the idea of diversity and inclusion in STEM as relevant topics of inquiry. The emails typically expressed overt anger, disgust, or hostility to the work and/or to the researchers. Departmental leadership and public relations specialists have been made aware of these incidents and expressed willingness to offer support if they escalate. Cech has also prepared graduate student research assistants on the project in the instance they encounter harassment as a result of their work on the project.

Riley $[4,5]$ has been targeted on three separate occasions since her appointment to Purdue was announced. The first, apparently in reaction to her hiring announcement, focused on an imagined horror that she would "queer engineering at Purdue" [6] and resulted in complaints directed at the upper administration. The second coincided with the Trustee's vote on her appointment in August [7] and was picked up by numerous right-wing media outlets, resulting in emails like the one included above and other harassment, threats, and intimidation directed at Riley and others at Purdue. The third coincided with the publication in December 2017 of a Distinguished Lecture delivered at ASEE in 2013 [8] and resulted in widespread targeting of Riley's social media as well as unwelcome contacts with her faculty and staff. Purdue Police and its Threat Assessment unit has worked with Riley and the department to secure the environment.

Farrell's work has been the subject of several articles in media outlets such as the Free Beacon, Daily Caller, Liberty Review and Campus Reform [9-14]. In general these articles present only the most superficial information publicly available through NSF award searches and faculty websites, and they sometimes disparage the researcher or the institution. Hashtags such as "government spending", "government waste", and "nutty professor" offer an anti-diversity perspective, and opinions are invited through public comments. Shortly after the first wave of media attention for Farrell's work to promote LGBTQ+ inclusion in engineering, Farrell's university produced a very positive article about this work and disseminated it regionally and 
nationally. The College also featured her work on the front page of an alumni mailing. In contrast to her colleagues who have received threats and hostile e-mails, Farrell has not been the subject of direct targeted harassment.

Pawley's circumstances are different from these colleagues. For the most part, she has been swept up in small instances of Riley's harassment, including in a video posted to Twitter targeting Riley, but which includes 2 snippets of video of Pawley speaking, with no acknowledgement that Pawley and Riley are different people. Her scholarly work has been the subject of on-campus ridicule - a colleague of a colleague let Riley (as Pawley's department head) know that a paper by Pawley focused on gender in engineering, along with another paper by a different departmental colleague, had been posted on a yet another colleague's door for a year to marginalize the state of research on gender in engineering education. This event was reported to the university Title 9 office given that both authors were women and the content was about gender research. Pawley also has been contacted by a Campus Reform reporter looking to report on a story on a recently published paper co-authored with Amy Slaton [15]. With no communication in response, the reporter seems to have not written anything about it. However, Pawley has also seen the harassment of Riley, and has undertaken various efforts to protect her own personal information, social media, and home address, and also acknowledges her fear of publishing work that could make her the subject of such similar harassment. Which, of course, is what the harassment is intended to do.

\section{Connection to LEES}

Math education researcher Rochelle Gutiérrez [16] has argued that the reason her community has been targeted recently is because it has begun to recognize more fully the value of analysis of power and privileges and incorporated this into their research. This is of particular relevance and interest for LEES Division members in that these analyses are ones that have traveled from the social sciences and humanities literatures and found applications in STEM education. Much of the work being targeted in engineering follows a similar pattern - scholarship that either focuses on relationships of power, on whiteness and masculinity, for example - and work that extends diversity categories beyond race and gender to include considerations of class, gender identity, and sexual orientation, feature prominently. At the same time, some attacks reveal a general antidiversity positioning and a belief in the inferiority or unsuitability of women and minorities for engineering.

The targeted harassment of STEM education researchers certainly seems to echo in both tone and tactics the decades-old attacks on political correctness and the emergence of women's and ethnic studies in the academy. At the same time, there appears to be an additional sense of outrage that these ideas are taking hold in STEM fields, and particularly in math and engineering, which are perceived or expected to be the most "objective" or least "political" fields, Here the first offense seems to be "crossing the streams" of disciplines [8] and daring to mix knowledge or ways of knowing with the social sciences. The epistemic commitments of at least some of the targeted researchers recognize how power matters, and acknowledge the authority of experience of members of diverse groups. To propose incorporation of culturally relevant material in math or engineering is to make visible the dominant cultures already present; these acts of harassment are a vehement and sometimes violent insistence on a "view from nowhere," [17], a depoliticization of engineering, [18] and a forced separation of the technical from the social. [19] 
Consider the characterization of the field's ideal as presented by Indrek Wichman [7]:

We engineers like to solve technical problems. That's the way we think, that's why we chose our major, that's why we got into and stayed in engineering. There are several other reasons why we got into engineering. One of them was the absence of what I describe here as "social engineering," where the professor/instructor is interested not so much in solving technical problems as in setting the world right.

Engineering is presented as purely technical and not only apolitical, but also amoral. Faulker [19] has shown how this technicist view of engineering is inextricably linked to hegemonic masculinity, creating challenges for both women and men in the engineering workplace. A comment on Wichman's article by RalphF reveals how a deficit model of diversity connects to this view point (as well as the false dualism of diversity/quality) [7]:

What will happen is that a whole new class of "engineer" will be produced that cannot do the work, but will still need to be hired. (Rest assured that companies will be forced by government to hire them.) Of course, real engineers will need to be hired to actually do the engineering work, basically costing companies twice as much as it should.

In this zero-sum game, any recognition that engineering work is sociotechnical in nature or any whiff of preparing engineers for the professional expectations of the 21 st century workplace is tantamount to technical disaster, as if professional skills are some kind of kryptonite erasing technical skillsets. Diverse engineers are presumed incapable and pitted against "real engineers." Yet ABET's new requirements for diverse teaming reflect the reality that if our students don't get basic training in power relations across categories like race, gender, class, ability, sexual orientation, gender identity, nationality, immigrant status, and veteran status, they will not be prepared to be engineers.

With hate crimes on the rise $[20,21]$ it can seem like we have stepped back in time, and day-today microaggressions can take on new meanings in this context. Now more than ever we need to address the root causes and build solidarity to dismantle systems of injustice.

\section{Scholarly and theoretical connections}

From a theoretical perspective, targeted harassment is an expression of power by advantaged group members over those who threaten ideas and practices that are hegemonic in the communities that provide that power [22]. Power of those who engage in targeted harassment is upheld by silence on the very issues that the targeted are raising to consciousness [e.g., 23-25]. Literature that has traced change and conflict within the partially-closed social worlds of professions demonstrates that the strength of such pushback is neither new nor unexpected [e.g. 26]. These scholars remind us that targeted harassment is not rooted in the idiosyncratic opinions of a few "bad apples," but is a result of structural processes within engineering that are driven by the inertia of centuries of defining "objectivity" and "good engineering" as the product of heterosexual middle-class white men [e.g. 17, 25, 27]. If not these individual harassers, there would be others. And there will be others. We can learn from scholars of the past and present to 
treat resistance to inequality-related work as evidence of the need to continue to push for change, not just the outrage of individuals whose power is being threatened.

How might past scholarship help buoy continued efforts to push for equality in STEM in the face of targeted harassment? First, we are building on twentieth century scholarship on intolerance. In the aftermath of the Holocaust, philosopher Karl Popper articulated (and traced back to Plato) the paradox of tolerance: that a tolerant society cannot permit intolerance to grow unchecked, "for it may easily turn out that they are not prepared to meet us on the level of rational argument...and answer arguments by the use of their fists or pistols. We should therefore claim, in the name of tolerance, the right not to tolerate the intolerant" [p. 226, 28]. Popper provides a moral clarity that helps us contextualize these specific experiences of targeted harassment in our community, connecting them to the broader context of intolerance on the rise globally in our present moment and in the patterns of history, urging us to act.

Second, we take to heart the observations of those who have faced backlash and opposition to their advocacy, theorizing power relations and change processes. For example, escaped slave and anti-slavery leader Frederick Douglass famously observed that "power concedes nothing without a demand. It never did and it never will." [29] Drawing this lesson from the abolitionist movement, we can theorize targeted harassment as another type of enacted power relations. This suggests that an appropriate response is to organize in order to demand that it stop. In this organizing work, we can learn from radical educator Myles Horton, founder of the Highlander Research and Education Center, who described in his autobiography the moment when he "grasped that the revolution had to be built step by step, that it wasn't going to come as a great explosion automatically. It had to be made, or it wouldn't happen. That's when I started saying 'Horton, get yourself together, get ready for the long haul and try to determine how you can live out this thing and make your life useful."' [p. 81,30]. Horton reminds us that change is made through deliberate, sustained efforts, and that cultivating our survival is part of the work.

Third, feminist and womanist philosophers have noted that one way to sustain each other for the long haul of justice work is by practicing an ethic of care [31]. According to Hill Collins, "the ethic of caring suggests that personal expressiveness, emotions, and empathy are central to the knowledge-validation process" [p.766, 31]. Our caring responses to targeted harassment - those that acknowledge the emotional toll on colleagues, that do the empathic work of repair - are in fact ways of building new knowledge and contributing to the scholarship of engineering education.

\section{Conclusion: Counting the Stakes, Calling for Action}

The NAE Report “The Engineer of 2020" [22] emphasized the importance of social context of engineering practice: "Attention to intellectual property, project management, multilingual influences and cultural diversity, moral/religious repercussions, global/international impacts, national security, and cost-benefit constraints will continue to drive engineering practice" [p. 28, 22].

It is well established that there is a critical need to diversify the STEM workforce to remain competitive in a global economy. Recognizing the need to attract and retain the most talented individuals to STEM professions, the National Academies advocate that diversity in STEM must 
be a national priority [23]. Furthermore, research suggests that improving diversity in a workforce has positive effects on innovation and productivity [24].

In order to pursue these priorities on behalf of our profession and the nation, STEM education researchers rely on academic freedom in order to explore new ideas, and widely share theories, methods, and promising practices across institutions and disciplines. Harassment, threats, and intimidation cannot be tolerated if we are to engage this call to the best of our abilities. It is crucial that all our students are able to realize their potential, and that our profession welcomes and cultivates talent to more fully enhance and protect the welfare of people and the planet.

Each of us is a potential ally to another STEM diversity researcher. We offer [35] a short acronym to help scholars remember how to respond in such an attack: RSR, for Report, Support, and Recommit. When a scholar is attacked, they (or a supportive colleague) should Report the attack to multiple bodies: the unit, college, and university levels; to law enforcement including campus and local police, state investigative units, and federal units like the FBI and Office of Civil Rights; and to non-profits monitoring these attacks nationally, like the AAUP, the American Association of Colleges \& Universities (AAC\&U) and the Southern Poverty Law Center. One can also report online attacks to online harassment support organizations like Heart Mob, Troll Busters, Crash Override, or Online SOS.

We then must provide Support to the person subjected to the attack. Do they feel physically and emotionally safe? Can someone else be asked to monitor the victim's email, social media, or mentions in the press? Colleagues can connect the victim to AAUP chapters and their Committee A groups, where impartial observers will accompany the victim (and take notes) at meetings with administrators about the harassment. Colleagues can also reach out to the ASEE Diversity Committee who can send indicators of support to the victim's supervisors, promotion and tenure committee, and whoever else needs to see it. We also encourage colleagues connect the victim with this paper's coauthors.

Finally, colleagues may need to prompt bodies like the unit's or college's communication team, or the university Senate, to Recommit publicly to the principles of academic freedom that protect faculty members' right to conduct research governed by the standards of their discipline. As an example, the ASEE Committee on Diversity, Equity and Inclusion worked with the executive board of ASEE to offer such a statement after the egregious attacks on Riley [36].

We might now augment this acronym with a $\mathrm{P}$ for Prepare: in advance of an attack on one's work or that of one's colleagues, one can start asking questions of an institution to find out what protections and processes are in place already should an attack begin, and whether the institution has an active chapter of AAUP present that could supply a member from "Committee A" (the committee on academic freedom and tenure) to serve as impartial observer when needed. (Perhaps the reader or reviewers can suggest a more harmonious arrangement or collection of letters for the resulting acronym.) One good institutional policy document to share with administrators was recently produced by the University of Iowa [37].

There are also other models for how to respond. Dana Cloud, a faculty member who has herself been the victim of targeted harassment, has offered 5 steps [38], which involve reversing the 
narrative of the attackers, finding allies to stand with the harassed, gain the support of major organizations (like AAUP, or ASEE) that defend academic freedom, obtain signatures from academics and allies everywhere, and get help for the victim with managing all this work.

LEES members in particular, as scholars who often bridge disciplines, can offer context and credibility from social science and humanities fields to help establish the legitimacy of inquiry, theories and methods used in STEM equity work. They can connect researchers under attack to networks of scholars more experienced in countering and resisting these efforts. And they can continue to network within ASEE in solidarity with the many other divisions committed to diversity to support ASEE's leadership in its efforts to defend academic freedom and meet the profession's and the nation's STEM diversity goals.

\section{Acknowledgements}

The authors would like to thank the ASEE Committee on Diversity, Equity and Inclusion for its support when different scholars have been targeted, and for making space in the 2018 ASEE program for some of this discussion. We would also like to acknowledge and appreciate all the people who are doing work, activism, or providing support to others in this space, including the Math Ed Collective, and the people who have already shared stories with us. We see you and we thank you.

\section{References}

[1] American Association of University Professors, "Statement of Principles on Academic Freedom and Tenure, 1940. [Online]. Available:

https://www.aaup.org/report/1940-statement-principles-academic-freedom-and-tenure. [Accessed: January 30, 2019].

[2] American Association of University Professors, "Targeted harassment of faculty: questions, answers, resources and support." January 26, 2018. [Online]. Available:

https://www.facebook.com/AAUPNational/videos/1819187414781402/ [Accessed Jan. 30, 2019].

[3] C. Quintana and B. Read, "Signal Boost: How Conservative Media Outlets Turn Faculty Viewpoints Into National News" The Chronicle of Higher Education, June 22, 2017.

[ONline]. Available: https://www.chronicle.com/article/Signal-Boost-How-

Conservative/240423 [Accessed Jan. 30, 2019].

[4] D. Riley, "Refuse, Refute, Resist: Alt-Right Attacks on Engineering and STEM Education Diversity Scholarship," Proc. CoNECD - The Collaborative Network for Engineering and Computing Diversity Conference, Crystal City, Virginia, 2018. https://peer.asee.org/29572.

[5] D. Riley, "Pipelines, Persistence, and Perfidy: Institutional Unknowing and Betrayal Trauma in Engineering." Feminist Formations, vol. 31 no.1, pp.1-19. Spring, 2019

[6] R. Dreher, R. "Queering Engineering at Purdue," The American Conservative, March 30, 2017. [Online]. Available: http://www.theamericanconservative.com/dreher/queerengineering-purdue-social-justice-warriors/ [Accessed Jan. 30, 2019].

[7] I. Wichman, "Engineering Education: Social Engineering Rather than Actual Engineering," August 2, 2017, James Martin Center, [Online]. Available: https://www.jamesgmartin.center/2017/08/engineering-education-social-engineering-ratheractual-engineering/ [Accessed Jan. 30, 2019]. 
[8] D. Riley, "Rigor/Us: Building Boundaries and Disciplining Diversity with Standards of Merit," Engineering Studies, 9:3, 249-265, 2017, DOI: 10.1080/19378629.2017.1408631

[9] R. Shimshock, “Taxpayers fund \$600K LGBTQ 'safe zone' study," The Liberty Review, September 18, 2017. [Online]. Available: https://thelibertyreview.com/engineering-safezone-gay-students-will-cost-taxpayers-500000/ [Accessed Jan. 26, 2019].

[10] M. Haverluck, “Taxpayers fund \$600K LGBTQ 'safe zone' study,” One News Now, September 19, 2017. [Online]. Available:

https://onenewsnow.com/education/2017/09/19/taxpayers-fund-600k-lgbtq-safe-zone-study [Accessed Jan. 26, 2019].

[11] E. Owens, "Federal Government Grants \$300k to Make Engineering Classes LGBTQaffirming," The Daily Caller, July 11, 2015. [Online]. Available: https://dailycaller.com/2015/07/11/federal-government-grants-300k-to-make-engineeringclasses-lgbtq-affirming/ [Accessed Jan. 26, 2019].

[12] E. Harrington, "Feds Spend $\$ 587,441$ to Make Engineering a 'Safe Zone' for LGBTQ Students," The Free Beacon, September 18, 2017. [Online]. Available: https://freebeacon.com/politics/feds-spend-587441-make-engineering-safe-zone-lgbtqstudents/ [Accessed Jan. 26, 2019].

[13] E. Harrington, "Feds Spend $\$ 299 \mathrm{~K}$ to Make College Engineering More 'Inclusive'," The Free Beacon July 9, 2015. [Online]. Available: https://freebeacon.com/issues/feds-spend299k-to-make-college-engineering-more-inclusive/ [Accessed Jan. 26, 2019].

[14] M. Barillas, "National Science Foundation to grant $\$ 300 \mathrm{~K}$ to make engineering more LGBTQ friendly," Campus Reform, July 10, 2015. [Online]. Available: https://www.campusreform.org/?ID=6660 [Accessed Jan. 26, 2019]

[15] A.E. Slaton and A.L. Pawley, "The Power and Politics of Engineering Education Research Design: Saving the 'Small N',' Engineering Studies 10 (2-3): 133-157, 2018, DOI: 10.1080/19378629.2018.1550785.

[16] R. Gutiérrez "Why Mathematics (Education) was Late to the Backlash Party: The Need for a Revolution," Journal of Urban Mathematics Education 10(2): 8-24, 2017.

[17] D. Haraway "Situated Knowledges: The Science Question in Feminism and the Privilege of Partial Perspective." Feminist Studies 14(3):575-599, 1988.

[18] E.A. Cech and H.M. Sherick, "Depoliticization and the Structure of Engineering Education," in International Perspectives on Engineering Education, S. Christensen, C. Didier, A. Jamison, M. Meganck, C. Mitcham, and B.Newberry, Eds. Cham, Switzerland: Springer, 2015, pp. 203-216.

[19] W. Faulkner, "Nuts and bolts and people': Gender-troubled engineering identities," Social Studies of Science, 37(3), 331-356, 2007. https://doi.org/10.1177/0306312706072175.

[20] B. Levin, J.J. Nolan, and J.D. Reitzel, "New data shows US hate crimes continued to rise in 2017," The Conversation, June 26, 2018. [Online]. Available:

http://theconversation.com/new-data-shows-us-hate-crimes-continued-to-rise-in-201797989. [Accessed Jan. 26, 2019].

[21] K. Müller and C. Schwarz, "Making America Hate Again? Twitter and Hate Crime Under Trump," Social Science Research Network, March 30, 2018. [Online]. Available: https://ssrn.com/abstract=3149103 or http://dx.doi.org/10.2139/ssrn.3149103. [Accessed Feb.2, 2019].

[22] A. Gramsci. Selection from the Prison Notebooks. New York: International Publishers, 1971. Pp. 323-35. 
[23] S.G. Harding. The Science Question in Feminism. Ithaca, NY: Cornell University Press, 1986

[24] S.G. Harding. Whose Science? Whose Knowledge? Thinking from Women's Lives. Ithaca, NY: Cornell University Press., 1991

[25] S.G. Harding. Is Science Multicultural? Postcolonialisms, Feminisms, and Epistemologies. Bloomington, IN: Indiana University Press, 1998.

[26] A. Abbott. The Systems of Professions: An Essay on the Division of Expert Labor. Chicago: University of Chicago Press, 1988.

[27] J. Des Jardins. The Madame Curie Complex: The Hidden History of Women in Science. New York: The Feminist Press, 2010

[28] K. Popper. The Open Society and Its Enemies Vol. 1: The Spell of Plato. London: George Routledge \& Sons, Ltd, 1945.

[29] F. Douglass. "The Significance of Emancipation in the West Indies." Speech given at Canandaigua, New York, August 3, 1857. Two Speeches by Frederick Douglass, Rochester, NY: C.P. Dewey, p. 22. Frederick Douglass Archives. Available: [Online]. https://www.loc.gov/item/mfd.21039/. [Accessed April 21, 2019]

[30] M. Horton, J. Kohl and H. Kohl. The Long Haul: An Autobiography. New York: Teachers College Press, 1998.

[31] P. Hill Collins. “The Social Construction of Black Feminist Thought.” Signs, Vol. 14, No. 4, Summer, 1989, pp. 745-773.

[32] National Academy of Engineering, The Engineer of 2020: Visions of Engineering in the New Century. Washington, D.C.: National Academies Press, 2004. [Online]. Available: https://www.nap.edu/read/10999/chapter/4

[33] National Academy of Sciences, National Academy of Engineering, and Institute of Medicine, Expanding Underrepresented Minority Participation: America's Science and Technology Talent at the Crossroads. Washington, D.C.: National Academies Press, 2011.

[34] C. Herring, "Does diversity pay?: Race, gender, and the business case for diversity," American Sociological Review, vol. 74, pp. 208-224, 2009.

[35] A.L. Pawley. E. M. Cech, S. Farrell, and D. Riley (2019). "Targeted harassment of engineering education researchers: How to connect with community and support your colleagues under attack" Presented at the Collaborative Network for Engineering and Computing Diversity (CoNECD) conference, Marriott Crystal Gateway, Crystal City VA. April 15-17, 2019.

[36] American Association for Engineering Education, "Letter Supporting Scholarly Research in Diversity and Inclusion in STEM Education.” [Online.] Available:

https://www.asee.org/documents/about-

us/theorganization/publicpolicy/LetterSupportingScholarlyResearchinDiversityandInclusion inSTEMEducation.pdf [Accessed Jan 31, 2019].

[37] University of Iowa Office of the Executive Vice President and Provost, "Faculty Support \& Safety Guidance," Available:

https://provost.uiowa.edu/sites/provost.uiowa.edu/files/Faculty_Support_Safety_Guidance.p df [Accessed Jan 31, 2019].

[38] D. Cloud (2017). "Responding to Right-Wing attacks." Inside Higher Education, November 7, 2017. [Online.] Available: https://www.insidehighered.com/advice/2017/11/07/tips-helpacademics-respond-right-wing-attacks-essay [Accessed Jan 31, 2019]. 